\title{
Türk Halı Sanatı Kompozisyonlarında Hayat ve Zaman Kavramları
}

\section{The Concepts of Life and Time in Turkish Carpet Art Compositions}

\section{Hakan Çiloğlu}

Dr. Öğr. Üyesi, Marmara Üniversitesi Güzel Sanatlar Fakültesi, Geleneksel Türk Sanatları Bölümü email: hakanciloglu@marmara.edu.tr DORCID ID: https://orcid.org/0000-0002-7461-2355

\section{Atıf (APA 6)/To cite this article}

Ciloğlu, H. (2019). Türk halı sanatı kompozisyonlarında hayat ve zaman kavramları. Atatürk Üniversitesi Güzel Sanatlar Enstitüsü Dergisi, 43, 200-213. doi: https://doi.org/10.32547/ataunigsed.604315

Makale Gönderim Tarihi/Received: 09/08/2019

Makale Kabul Tarihi/Accepted: 02/10/2019

Makale Yayın Tarihi/Published: 26/10/2019

Research Article/Araştırma Makalesi

\section{$\ddot{\mathbf{O z}}$}

Türk kültürünün önemli bir halkası olan halı sanatının sonsuzluk ve gökyüzü kompozisyonlarında, hayat ve zaman kavramları gizlidir. Çünkü insanın en önemli farkındalığı, tekrarı yaşanamayan hayat ve zamandır. Coğu insan için gençken hayat ve zaman kavramlarının değeri bilinemese de, güneşin günbatımına yönelmesi gibi evrede hayat ve zaman kavramları önemini daha çok hissettirir. Görmeyi bilen ve düşünen insan için hayat ve zamanın ne olduğu, gökyüzü ve yaşamdaki pek çok olayda gözlemlenebilir. "Güneșin doğuşu ve batışı arasındaki çizginin hayata dokunuşunu hissedemeyenler, hayatı diğer canlılar gibi yașarlar." Gökyüzünde ayın evrelerinde, ya da hilal görünümünde, ya da sonbaharda düşen bir yaprakta; başladığ 1 noktadan artarak güçlenen ve tekrardan azalarak biten etkisinde hayatın kendisini görmek mümkündür. Cünkü hayat; miktarı değişen çizgisiyle yarım daire gibidir ve her bir hayatın kendi zamanı vardır. Hayat belirli bir yol, yaşam bu yolda gidişler ve zaman ise bu yolun başından sonuna geçen süre olarak düşünülebilir. Hayat ve zaman kavramları kare gibi kararlı ve durağan yapıdadır ve hayat; zamanın değișmeyen kararlı yapısının bir parçasıdır. Hayatın çizdiği yolda hareket, aktiflikler ve durağanlıklar zamanda farklı etkilerle yaşanır ve her bir hayat süresi içinde yaşamda değișen kavramlar oluşur.

$\mathrm{Bu}$ araştırmada; hayatın içinde farklı zaman süreçlerinde başlayan ve biten kavramlara dayalı olay ve görünümlerin iç dünyada oluşturduğu sonsuzluk özlemiyle, Selçuklulardan günümüze Türk halı sanatının farklı geometrik kompozisyonlarında gökyüzü, yıldız desenleri ve motiflerle yer aldığg görülmüştür. Orta zeminde anlam kazanan sonsuzluk ve hayatın bilinen kararlı yapısının dışına çıkılamayacağı bilinci, kare ve dikdörtgenlerin kararlı alanı içinde desenlenmiştir.

Anahtar Kelimeler: Halı, Sanat, Kompozisyon, Hayat, Zaman

\begin{abstract}
The concepts of life and time are hidden in the eternity and sky compositions of carpet art, which is an important part of Turkish culture, because the most important awareness of human beings is life and time which cannot be repeated. Although the value of life and time is not known for most people when they are young, the concepts of life and time are more important in the stage of the sun turning into the sunset. What life and time are for the person who knows and thinks to see can be observed in many events in the sky and life. "Those who cannot feel the touch of the line between sunrise and sunset, live life like other creatures." In the phases of the moon in the sky, or in the appearance of a crescent moon, or on a leaf falling in autumn; it is possible to see life itself under the effect of increasing and decreasing again from the point where it started. Because the amount of life is like a semicircle with a changing line and each life has its own time. Life can be thought of as a certain path, life on this path, and time as the time from the beginning to the end. The concepts of life and time are stable and stationary, such as the square, and life is part of the unchanging stable structure of time. On the path drawn by life, movement, activities and stagnations are experienced with different effects in time and concepts that change in life occur within each life span.

In Turkish carpet art, the awareness of life and time seen from the Seljuks to the present day has been seen with different compositions featuring sky, star patterns and motifs shaped by emotions and thoughts as the sky represents infinite time, greatness and power. The eternity is the fundamental thought in Turkish carpet art compositions. Infinity that gains meaning in the middle ground and awareness that life cannot go beyond the known stable structure of life is patterned within the stable area of squares and rectangles.
\end{abstract}

Keywords: Carpet, Art, Composition, Life, Time

\section{Giriş}

Bünyesinde zengin kültür birikiminin tarihi eserlerini bulunduran ülkemizin, en önemli sanat dallarından biri Türk halı sanatıdır. Yaşamın vazgeçilmez kullanım eşyası olan halılar, fonksiyonel ve teknik yapısının yanında gözlem, düşünce ve üstün yorumlama gücünü sergileyen kompozisyonlarındaki başarılarından dolayı, kültürümüzün en önemli temsilcilerindendir. Kompozisyonlarda gözlemlenen hayat - zaman bilincinin gökyüzü ve sonsuzluk özlemi, duygulara dokunan dönemsel ve bölgesel desen ve motiflerle anlam kazanarak, başarılı bir yol izlemiştir.

Hayat; kelime anlamı olarak çoğu kez yaşamla aynı açıklanır. Yaşam; hayatın içinde biçimlenen detaylarıdır. Hayat ise sonsuz zamanda yer alan ve algılanabilen her varlığın kendisine ait yaşam evrelerini içeren genel bir kavramdır (TDK, 1988, s. 624). İnsan dışında diğer canlılar kendilerine sunulan hayatı yaşarken, yalnızca hayatta kalma mücadelesi verirler. Fakat insan; farkındalığıyla hayat ve zaman konusunda her detayı sorgulayarak, görünenin arkasındaki gerçeği araştırır (Hançerlioğlu, 1995, s. 20). Hayat ve zaman kavramları 
insana özgü ve insanın tanımlamada en çok zorlandığı, düşündürücü kavramlardır. Bu nedenle felsefenin alanına girmekle birlikte, fizik ve metafiziğin de araştırma konuları arasındadır (Ana Britannica, 1990, s. 527; Thomson, 1976, s. 21). İnsan farkındalık sahibi olmaya başladığı andan itibaren hayat ve zaman kavramlarını düşünmüştür. $\mathrm{Bu}$ nedenle hayat ve zaman için sözler pek çok kişi için derin anlamlar ifade eder ve insanlık tarihinden günümüze belki de en anlamlı sözler hayat ve zaman için söylenmiştir ve söylenecektir.

Dünyada pek çok insan üzerinde yaşadığı doğayı ve yaşamı sorgulamadan, kendilerine sunulan hayatı yaşarlar. Fakat hayatı gözlemleyen ve farkındalığıyla düşünen insanlar, aktifliklerle dolu yaşamın bilinen sonun dışına çıkılamayan kararlı, akan fakat değişmeyen zamana bağlı sonlandığını bilir ve yaşam sürecinin en iyi kazanımlarla geçmesi için çalışırlar. Çünkü hayat ve zaman; telafisi olmayan kavramlardır. Çoğu insan için gençlik döneminde hayat ve zaman kavramlarının değeri çok bilinemese de, güneşin günbatımına yönelmesi, ya da yaprağın sonbaharda solmaya başlaması gibi evrede hayat ve zaman kavramları önemini daha çok hissettirir ve dramatik bir anlam kazanır. Toplumda hayat için; hayatta, hayatını yaşıyor, hayatını kaybetti, hayatta değil gibi farklı sözler işitmek mümkündür. Bu nedenle başlangıç ve bitişten oluşan hayatın sonsuz zamanda durumunu belirten en güçlü kavram; varlık ve yokluk kavramlarıdır.

Geçen zamanı somut bir şekilde göstermek mümkün değildir. Yağmurda 1slandığımızda şeffaf olan suyu görür, rüzgârda göremediğimiz havayı hissederiz. Fakat zaman; elle tutulamayan, gözle görülemeyen; yalnızca doğa ve uzaydaki olayların izlediği yolun gözlemlenmesiyle bilinen bir gerçektir (Hançerlioğlu, 1989, s. 356; Hançerlioğlu, 1993, s. 471).

\section{Yöntem}

Araştırma Betimsel bir modelle yürütülmüştür ve Betimsel modele dayalı Nitel bir araştırma özelliğindedir. Hayatın belirli zaman sürecinde başlangıç ve bitişi kapsadığı, hayat ve zamanın gökyüzü, doğa, varlıklar ve yaşamdaki pek çok olayın görünüm ve etkilerinde, artan - azalan, değişen durumlarının gizli anlatım biçimleriyle görülebildiğine dair araştırma, gözlem ve incelemeleri yapılmıştır. Bu araştırmada hayatın içinde görülen varlıkların yapılarındaki ve hayatta yükselen - inen değerlerle yaşamda oluşan farklı kavramların kare, üçgen ve daire ile ilişkisinin nedenleri incelenerek, gözlem ve düşünceye dayalı ortak söylemleri geometrik şekillerin kavramsal özellikleriyle açıklanmıștır. Araştırmada insan yaşamına yön veren hayat ve zaman farkındalığı ve iç dünyada biçimlenen sonsuzluk özleminin Türk halı sanatı tarihi gelişiminde farklı geometrik kompozisyonlarla aldığı yer incelenmiştir. Güneş, ayın evreleri, gökyüzü, mevsimler, bitkiler gibi örneklerde başlangıçtan bitişe giden yolda kendi içindeki etki ve görünüm değişimleri gibi yaşamdaki doğal olayların, Türk halı sanatı kompozisyon, desen ve motiflerindeki kavramsal söylemi aranmıştır. Kompozisyon, desen ve motiflerin analizleri yapılarak, seçilen örneklerin hayat, zaman ve sonsuzluk kompozisyonları yine geometrinin kavramsal özellikleriyle açıklanmıştır.

\section{Hayat ve zaman kavramlarının yaşamda gözlenmesi ve örneklerle anlatımı}

Görmeyi bilen ve düşünen insan için hayat ve zamanın tanımı gökyüzü ve yaşamdaki pek çok olayda görülebilir. Bir grup kuşun yerden havalanırken aralarındaki zaman farkında, ya da dünya dönerken farklı yerlerde güneşin doğuşu ve batışındaki zaman farkında, ya da küçüklükten yaşlılığa giden yaşanmışlık farkında hayat ve zaman kavramları gözlemlenebilir (Görsel 1).

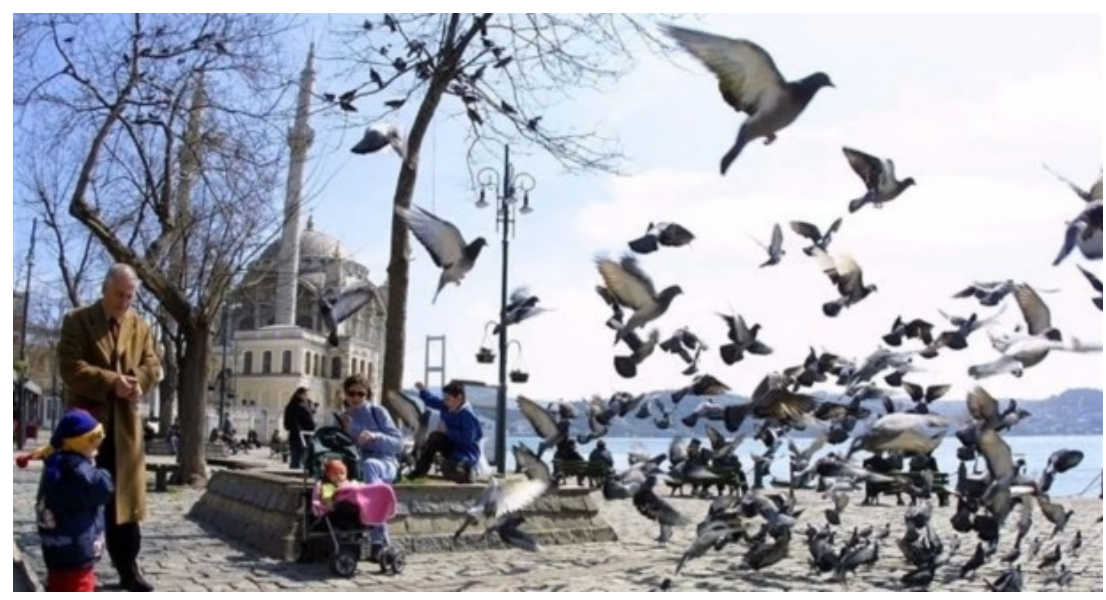

Görsel 1. Havalanan kuşlar ve bebeklikten yaşlılığa insanlar arasında hayat ve zaman farklılığ1

Hayat; belirli bir yol, yaşam; bu yolda gidişler, zaman ise ömür denilen yolun başından sonuna geçen süre olarak düşünülebilir. Hayat ve zaman kavramları kare gibi kararlı ve durağan yapıdadır ve hayat; zamanın değişmeyen kararlı yapısının bir parçasıdır (Görsel 2). 


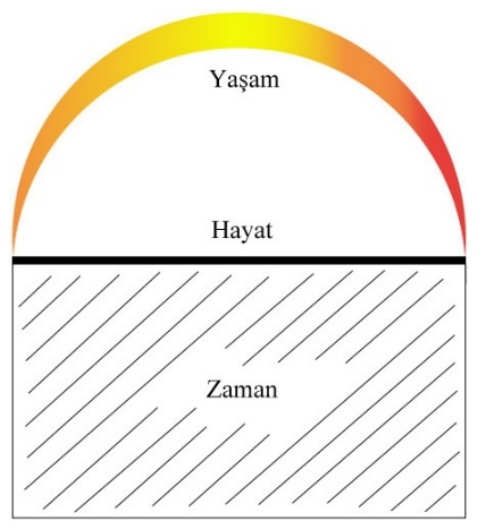

Görsel 2. Zamanda hayatın yaşam evreleri

Dünyanın her yerinde, her an yeni hayatlar başlarken, başka hayatlar da sona ermektedir. Gökyüzünde ayın evrelerinde, ya da hilal görünümünde, ya da sonbaharda düşen bir yaprağın yüzeyi ve renk tonlarında hayatın başlangıçtan bitişe giden yolunu ve kendisini görmek mümkündür (Görsel 3 -5).

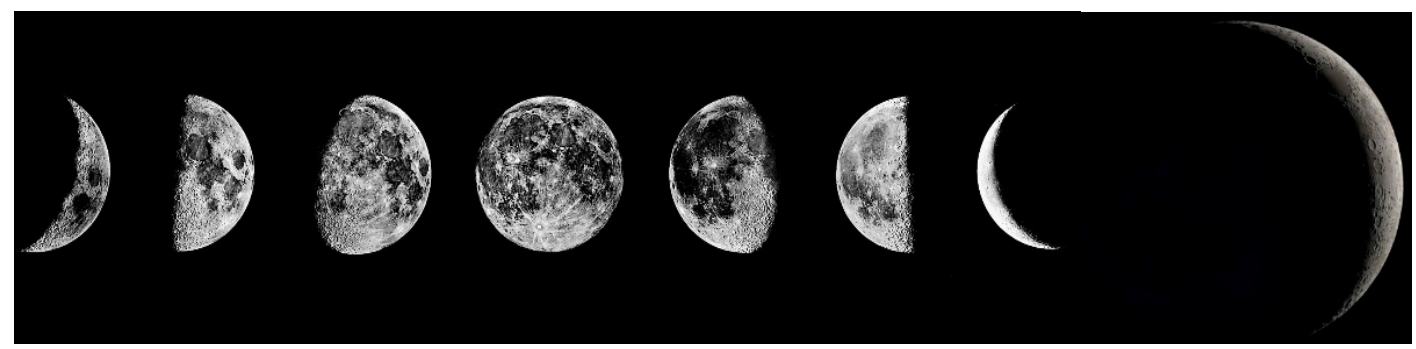

Görsel 3. Ayın evreleri ve hilal görünümünde başlangıç - bitiş etkisi

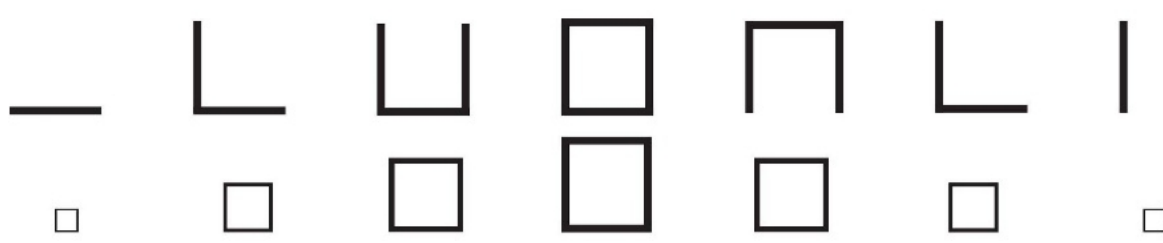

Görsel 4. Ayın evreleri ve hayatın kararlı yapısının kare ile miktar çizimi

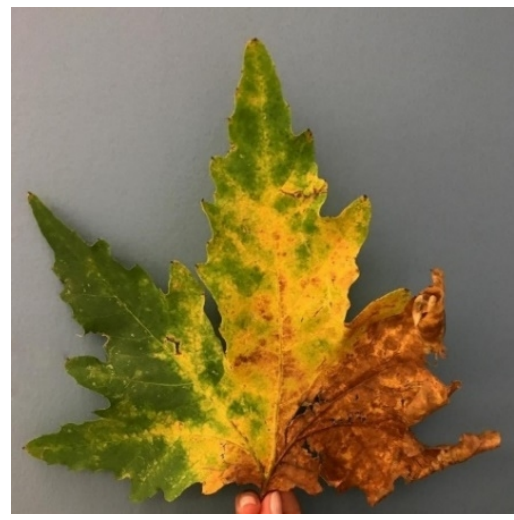

Görsel 5. Bir çınar yaprağında hayatı gözlemlemek

Gözlem, araştırma, düşünme ve bilimden uzak, farkındalığı olmayan insanların hayatları başlar ve biter. Aslında hayat ve zaman insanın bedeninde gizlidir. Hayat süresince gelişim ve yaşlanma etkilerinden farklı, insan kendi eline baktığında küçük parmaktan başlayarak uzayan, genişleyerek güçlenen ve tekrardan kısalan yapısında hayatın kendisini görebilir. Hayat boyunca el; yaşamı üstlenir ve çocukluktan itibaren pek çok yeteneği öğrenir. Elin gelişiminde ve yaşlılıkla aktifliğindeki gerilemede hayat, zaman ve yaşamın etkileri görülebilir. İşaret parmağı neyi gösterirse hayat da onu gösterir. Başparmak ise, dört parmağın kararlılıkla hayata bağlanma ve elin kilitlenmesi görevini üstlenir (Görsel 6). 


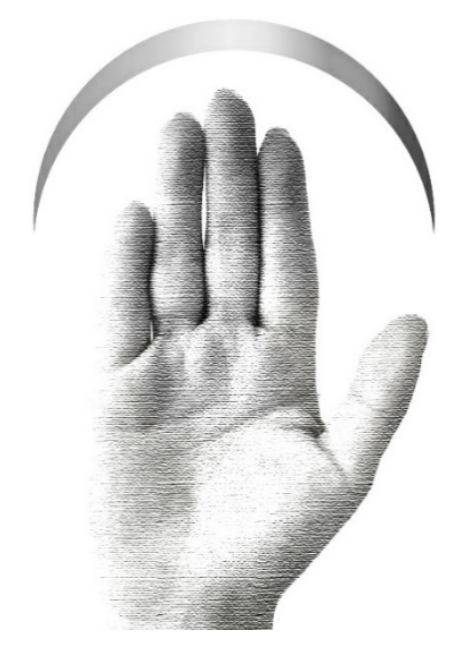

Görsel 6. Hayatı ve yaşam sürecini elin yapısında gözlemlemek

Başlangıç ve bitişten ibaret olan hayat; zaman içinde miktarlarla değişen pek çok yaşam kavramları içerir. Hayat sarı 1şıkla başlar, kırmızı 1şıkla sona erer (Görsel 7 - 8). "Güneşin doğuşu ve batışı arasındaki çizginin hayata dokunuşunu hissedemeyenler, hayatı diğer canlılar gibi yaşarlar.” Çünkü hayat inceden kalınlaşan ve tekrardan incelen çizgisiyle yarım daire gibidir ve her hayatın kendi zamanı vardır (Görsel 2). Mevsimlere göre güneşin doğuşu ve batışı sürelerindeki değişim buna en iyi örnektir.

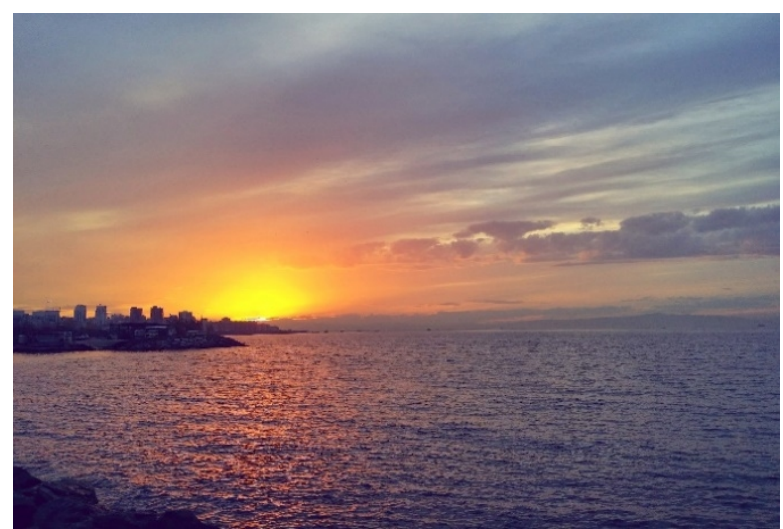

Görsel 7. Güneşin doğuşunda sarı 1ş1k etkisi

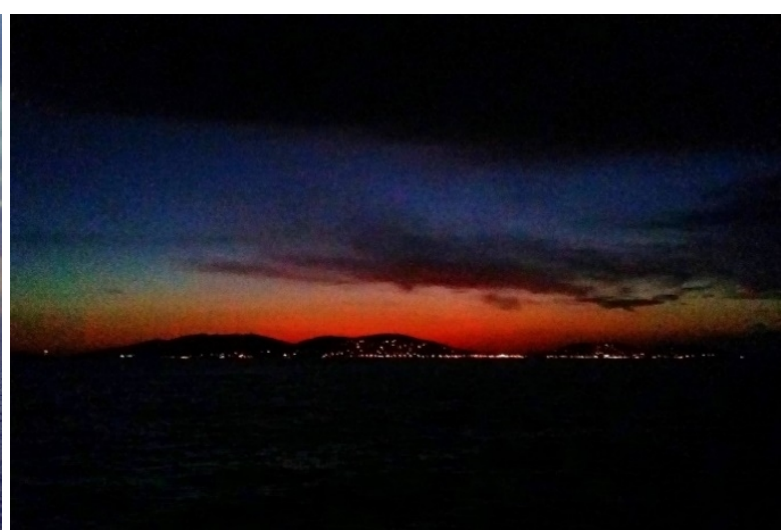

Görsel 8. Güneşin batışında kırmızı 1şık etkisi

Rüzgârlı bir sonbahar gününde bir çınar ağacına bakıldığında sararmış, ya da saramaya yakın büyük yaprakların da, küçük yaprakların da düştüğü görülür. Genelde sıralı hayatın sonlanacağı düşünülse de arada büyük de düşer, küçük de (Görsel 9).

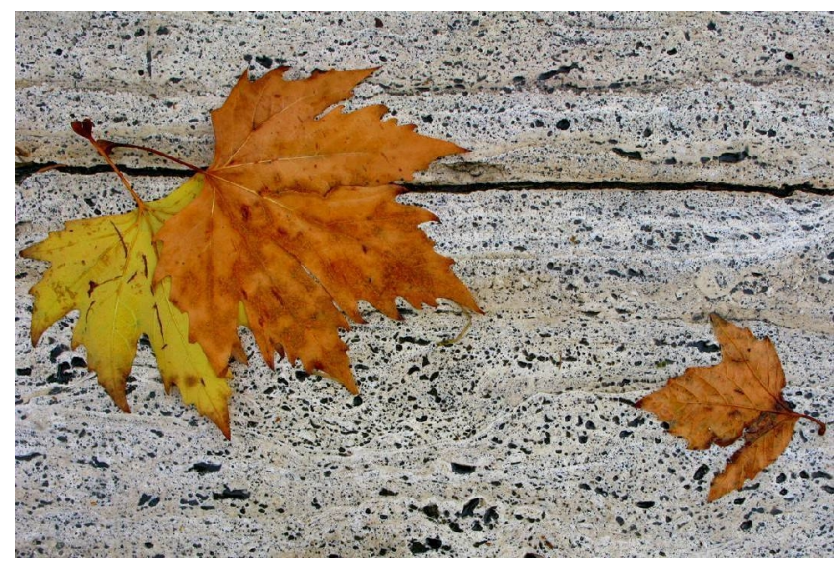

Görsel 9. Sonbaharda düşen büyük ve küçük yapraklar 
Hayatın geçmişi bilgi ve tecrübeler bütünü, geleceği ise umut, sevgi ve beklentidir. Bu durum insanı hayata bağlayan en büyük güçtür. Örneklerini tüm yaşanmışlıklarla doğada çiçek açan bitkiler ve yenilenen yapraklarda görmek mümkündür. Hayat üzerine yaşam tecrübesi kadarıyla herkes pek çok söz söyleyebilir ve insan yaşamı var olduğu sürece de söylenecektir. Fakat sözler değişse de, değişmeyen tek gerçek hayatın başlangıç ve bitişidir. $\mathrm{Bu}$ nedenle insanın en büyük özlemi sonsuzluktur ve insanlar ömür denilen gelip geçen hayatta yaşama ve geleceğe katkıda bulunmak, yapıtlarıyla dünyada kendilerinden iz bırakmak isterler.

Hayat; zaman sürecinde hangi yaşam süreçleriyle karşılaşılacağı bilinemeyen bir kavramdır. Her gelecek an sürprizlerle doludur. Örneklerine yine doğada rastlamak mümkündür. Bazen hiç ummadığımız yerde hayat buluruz (Görsel 10). Bazen de bulduğumuzu zannederiz (Görsel 11). Geride bizden bir şeyler kalsın isteriz (Görsel 12).

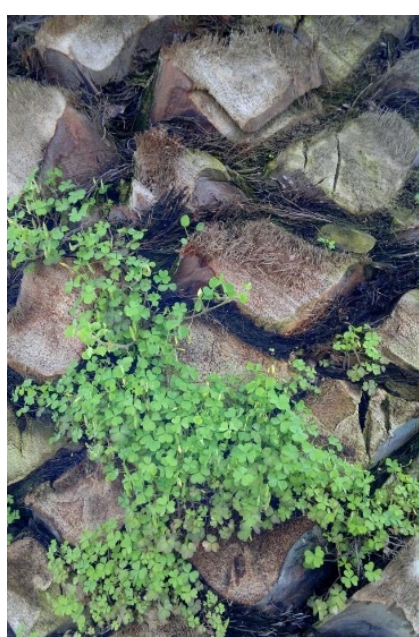

Görsel 10. Palmiye gövdesinde hayat bulan bitki

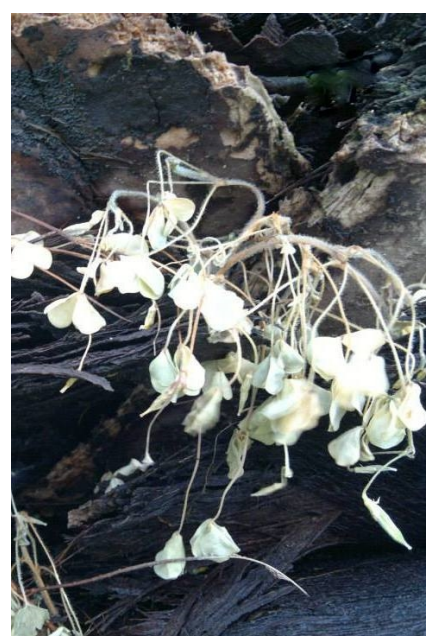

Görsel 11. Palmiye gövdesinde hayatı sonlanan bitki

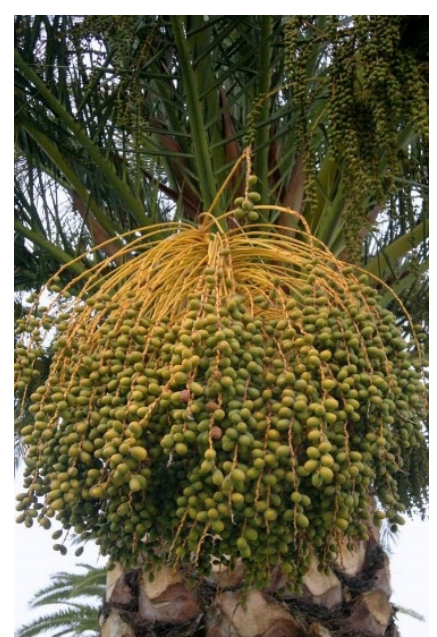

Görsel 12. Palmiye ağacı tohumları

Hayatın çizdiği yolda hareket, aktiflikler ve durağanlıklar zamanda farklı etkilerle yaşanır ve her bir hayat süresi içinde yaşamda değişen kavramlar oluşur. Hayatın kare gibi kararlı yapısı ve zaman çerçevesinde çıkışlı - inişli biçimlenen bu etkiler kare, üçgen ve dairenin yapısı ve kavramsal özellikleriyle açıklanabilir. Bu kavramları canlı - cansız varlıkların kendi özelliklerinde görmek mümkündür. Doğada bütünün parçalarından aktiflik ve sertlik içeren bölümler ve olaylar üçgen, hareket ve yumuşaklık içerenler daire, durağanlık ve kararlılık içerenler de kare ile ilişkilendirilebilir. Topraktan yeni çıkan, ya da büyüyen bir bitkinin kendini koruma biçimlerinin nedenleri aktif üçgen yapılarında görülebilir (Görsel 13).

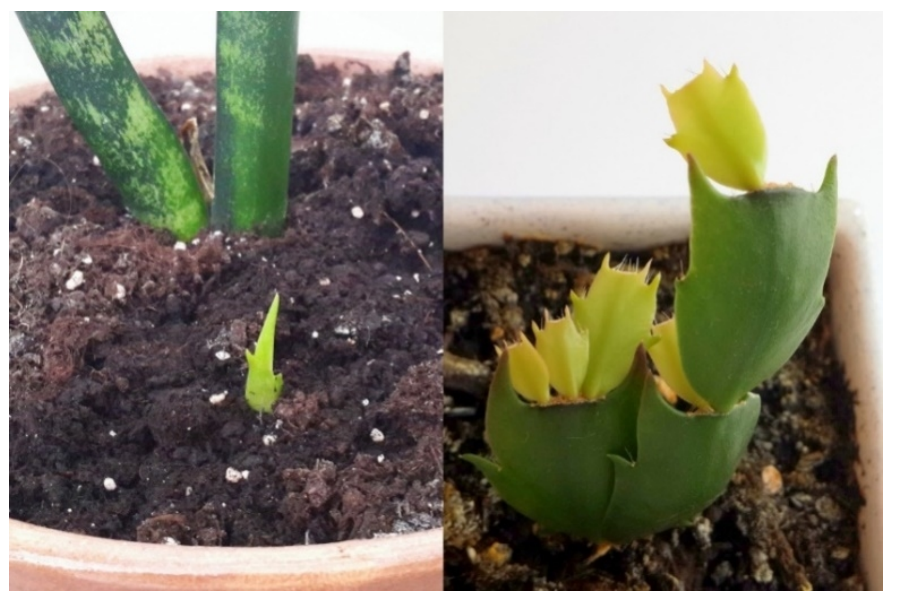

Görsel 13. Topraktan yeni çıkan ve büyüyen bitkilerin üçgen yapısı

Doğaya baktığımızda; bir bitkinin önce ve sonra çıkan yapraklarında farklı hayatları, bir yaprakta küçükten giderek büyüyen ve tekrardan küçülen bölümleriyle hayatın sürecini ve saptan aktif üçgenlerle genişleyerek yükselen ve tekrardan zirveden tekrardan sapına dönen çıkışlı ve inişli yapısında, hayatın kendisiyle yaşamda 
başlayan ve biten tüm kavramlar düşünülebilir (Görsel 14). Çünkü hayatta her çıkışın bir inişi vardır. Zirvede ancak özlemlerde ve anılarda kalınabilir.

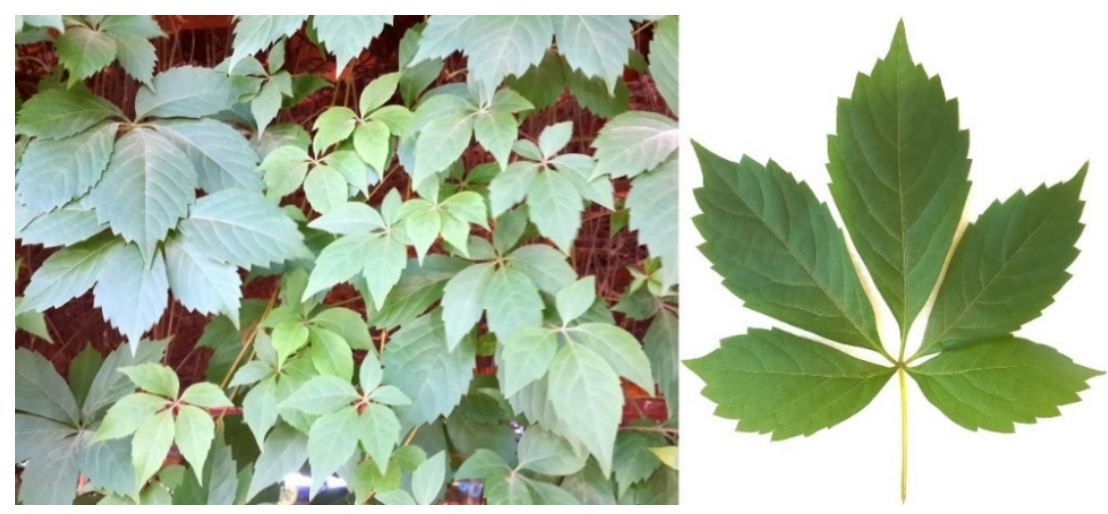

Görsel 14. Önce ve sonra büyüyen yapraklarda ve bir yaprağın noktadan başlayarak tekrardan aynı noktaya dönen yapısında yaşam evreleri ve hayatın temsili

\section{Türk halı sanatında hayat ve zaman kavramları}

Hayat ve zaman kavramları farkındalığı, Selçuklulardan günümüze duygularla şekillenen gökyüzü, yıldız desenleri ve motiflerin yer aldığı farklı kompozisyonlarla görülür. Kompozisyonlar ve desenler değişse de, hayatın bilinen kararlı yapısının dışına çıkılamayacağı bilinci kompozisyonlarda kare ve dikdörtgenlerin kararlı alanı içinde sonsuzluk özlemi ve gökyüzü anlatımlarıyla şekillenir. Çünkü gökyüzü; sonsuz zaman, büyüklük ve gücü temsil eder ve sonsuzluk Türk halı sanatı kompozisyonlarında temel düşünceyi oluşturur.

Günümüze kalan örneklerden 13. Yüzyıl Konya, Selçuklu halısında orta zemininde tekrar eden aynı motiflerin sonsuzluk kompozisyonu; yaşamda akıp giden olayların değişen aktifliklerini içeren üçgen desenli geniş bordürle çevrelenerek durdurulmuştur. Geniş bordürün her iki yanında gökyüzünün ve sonsuzluğun simgesi, yıldız motiflerinden oluşan ince bordürler bulunmaktadır (Görsel 15).

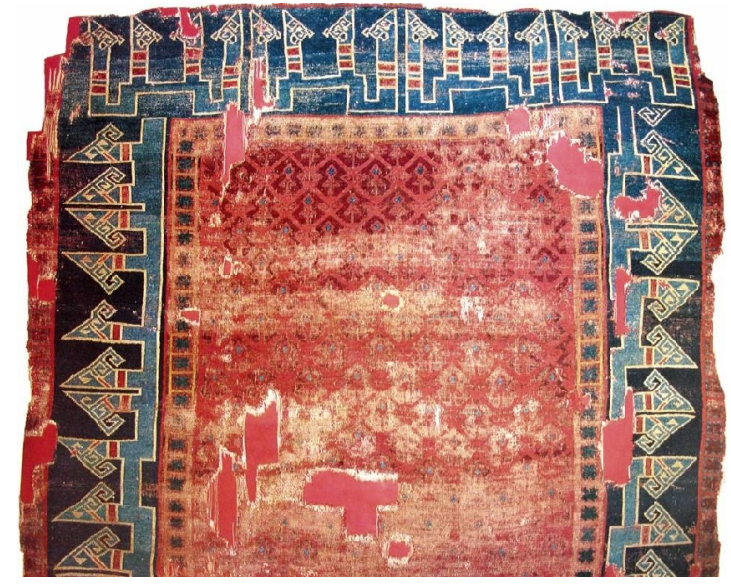

Görsel 15. Konya, Selçuklu, 13. yüzy1l. 285x520 cm, İstanbul, Türk ve İslam Eserleri Müzesi, Env. No: 681

16. Yüzyıl Uşak halısının kırmızı orta zemininde bitkisel ya da güneşin parlayan ışınları gibi gökyüzü olaylarını temsil eden sarı desenler, yine sonsuzluk prensibiyle tekrar etmektedir. Orta zemini çevreleyen mavi zeminli geniş bordür içinde yan, yana dizilimli bulut motifleri, halının genel kompozisyonunun hayat ve geçen zamanın sonsuzluğa duyulan özlemle gökyüzü anlatımını düşündürmektedir (Görsel 16). 


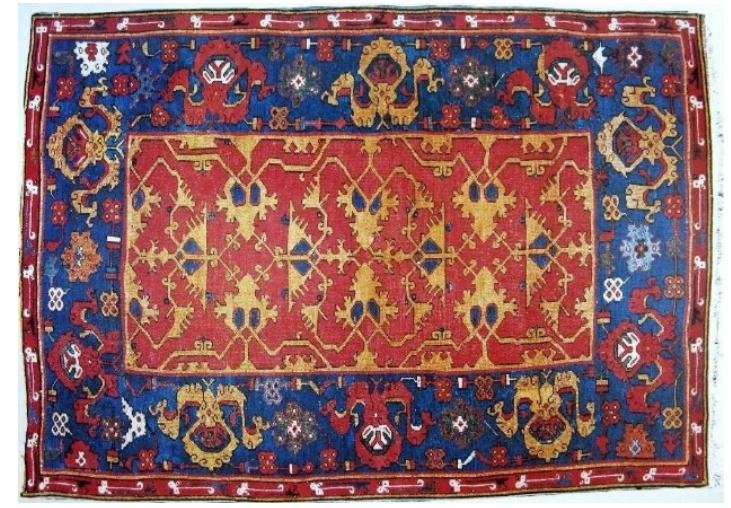

Görsel 16. Uşak, 16. yüzy1l. 119x168 cm. özel koleksiyon

18. Yüzyıl Antalya, Döşemealtı halısının orta zemini; gelip, geçen hayat ve zamanın sonsuzluğa duyulan özlem kompozisyonudur. Dizilimli sekizgenler içinde yıldız motifleri yine sonsuz gökyüzünü, aralarda yer alan motifler ise, hayat ve zamanın kare gibi kararlı yapısını simgeler. Orta zeminin sonsuzluk kompozisyonunu çevreleyen kare motifler dizilimli beyaz zeminli bordür ise, bilinen sonun dişına çıkılamayan ve sonsuzluk özleminin yalnızca duygularda bırakıldığg, yaşamdaki tüm hareketlilik ve enerjiye rağmen hayat ve zamanın kare gibi kararlı ve durağanlığını temsil etmektedir (Görsel 17).

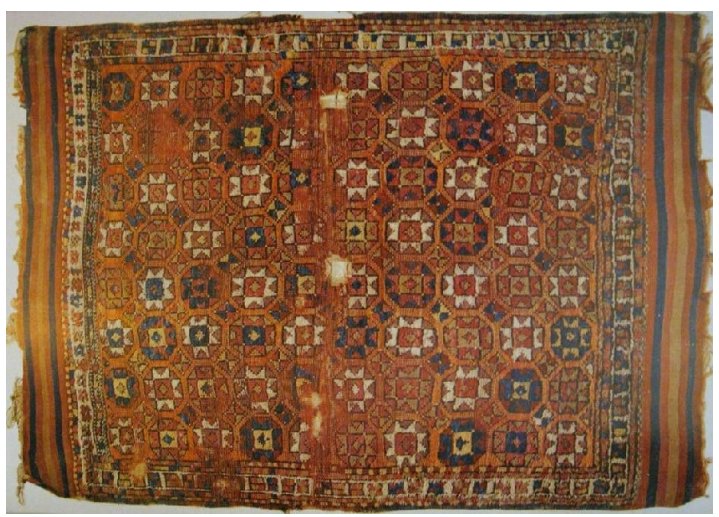

Görsel 17. Antalya, Döşemealtı, 18. yüzyıl.143x196 cm. Türk ve İslam Eserleri Müzesi, Env. No: 681

18. Yüzyıl Bergama halısına bakıldığında orta zeminin sonsuzluk kompozisyonu Türk halı sanatında çok karşılaşılan desenle görülür. Farklı renklerle, ikişerli dizilen aynı desenler ve ortasında sekizgenler içindeki yıldız motifleri; gökyüzünde kendi özellikleriyle görünen oluşumların sonsuzluğunu anlatır. Sekizgenli yıldız motiflerinin etrafı; dört ayrı kenarında yaşam basamaklarını simgeleyen üç küçük karenin, hayat ve zamanın kare gibi kararlı yolunun farklı renklerle şekillenmesidir. Beyaz zeminli geniş bordürle orta zeminin sonsuzluğu durdurulmuştur. Bordür deseni yaşamda kararlı başlayan ve biten kavramların dört yapraklı bitkisel motif ve yine hayat ve zamanın kararlı yapısını temsil eden karelerin tekrarıyla yer almaktadır (Görsel 18).

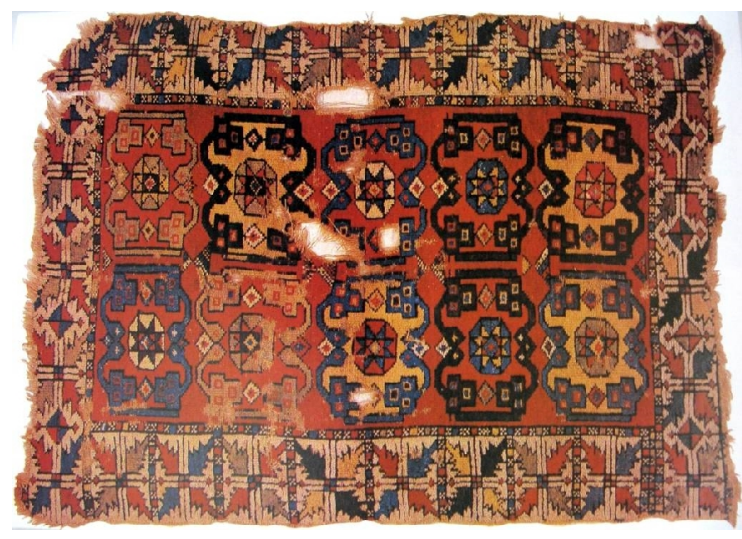

Görsel 18. Bergama, 18. yüzy1l. 133 x 187 cm. özel koleksiyon 
18. Yüzyıl Uşak halısında sekiz uçlu desenin yarım, tam ve yarım yer alması orta zeminde sonsuzluk kompozisyonu oluşturmasıyla birlikte, diğer açıdan hayat ve zaman sürecinde yaşamda başlayan, gelişen ve biten durumlar gibidir (Yetkin, 1991, 93). (Görsel 19).

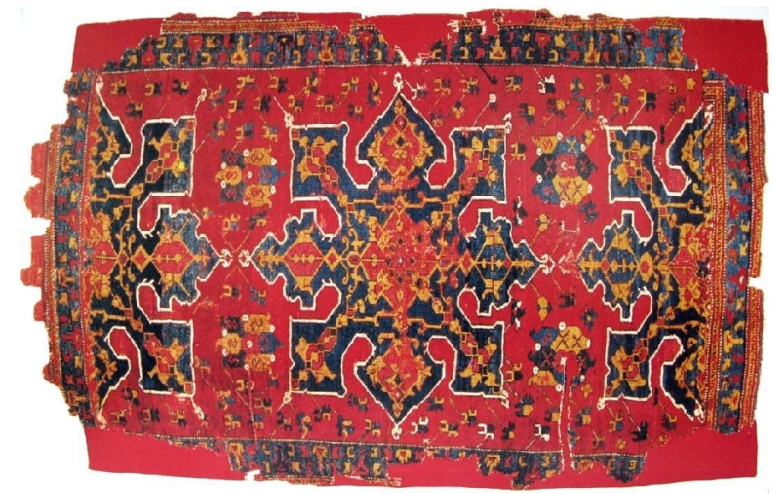

Görsel 19. Uşak, 18. yüzy1l. 130x207 cm. İstanbul, Vakıflar Halı Müzesi, Env. No: 766

17. Yüzyıl Çanakkale halısında hayat ve zaman farkındalığının yarattığı sonsuzluk duygusu, yine gökyüzünün büyüklüğü ve sonsuzluğu temsil eden desen ve motiflerinin farklı kompozisyonunda anlam kazanmıştır. Tekrar eden beyaz zeminli büyük sekizgen desen; lacivert zeminli üçgen desenlerle güneş ya da dünyanın kararlı dönen hareket yapısı gibidir. Aralardaki güneşin doğuşu - batışı, dünyanın düzenli dönüş hareketi ve uzak yıldızları temsil eden gökyüzü kavramlarıyla sonsuz zamanda hayatın kararlı yapısına karşı, sonsuzluğa duyulan özlemi temsil eden küçük yıldız motifleri bulunmaktadır. Yine; sekizgenin merkezini saran küçük kareler zamanda kararlı ve düzenli hareket yapısını göstermektedir. Orta zeminin köşelerinde yer alan dönen motif, sekizgenin bir gezegen, galaksi ya da gökyüzü hareketinin olduğu düşüncesini güçlendirmektedir. Büyük sekizgen desenlerin arasında, zaman sürecinde yaşamdaki aktiflik ve enerjiyi temsil eden üçgen desenler bulunmaktadır. Orta zemini çevreleyen, küçük karelerden desenlenen geniş bordür hayat ve zamanın kararlı anlam yapısındadır (Görsel 20).

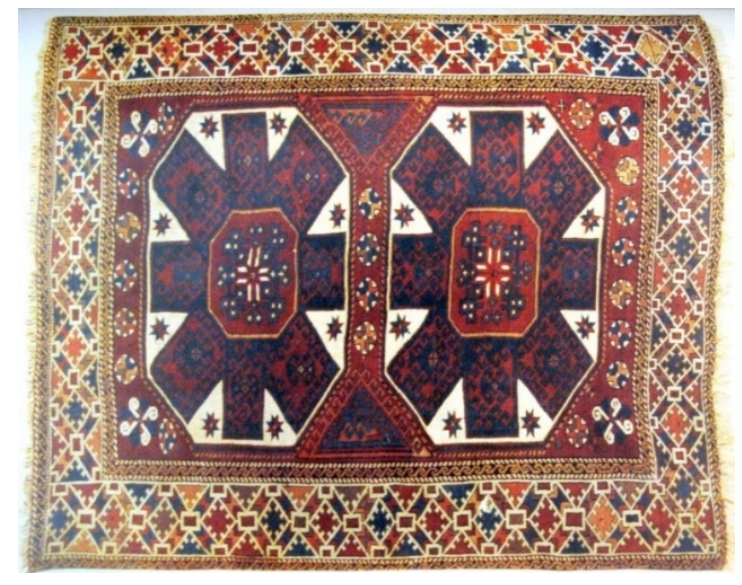

Görsel 20. Çanakkale, 17. yüzy1l. New York, The Metropolitan Museum of Art

18. Yüzyıl Konya, Karapınar halısının orta zeminini çevreleyen ince, beyaz çizgi hayat ve zamanın kararlı yapısını temsil ederken, dikdörtgenler içinde, toprak ve gökyüzü renklerinde iki büyük yıldızda hayat ve sonsuzluk düşüncesi görülmektedir. İki yıldızın içindeki motifler, toprak ve gökyüzünün ötesindeki bilinmezliği düşündürür. Yıldızları çevreleyen sekizgenlerin beyaz üçgen çizgilerinde yaşamda miktarları değişen hareket ve duyguların kavramları gizlidir. Yıldızların ve sekizgenlerin köşelerinde yer alan iç, içe üçgenler geçen zamanı anlatmaktadır. Koyu zeminli yıldız desenli sekizgenin köşelerde iç, içe üçgenleri çevreleyen ve birbirine bağlayan mavi üçgenler, yaşamda miktarlarla değişen olayları, mavi yıldız desenli sekizgeni çevreleyen ve birbirine bağlayan sarı üçgenler ise, yine aynı anlamla birlikte, gökyüzünde yıldızların pırıltısı, 1şık, enerji, yıldızlara ve gökyüzünün sonsuzluğuna duyulan özlemi anlatmaktadır. Geniş bordür orta zemin rengiyle aynı olmakla birlikte, yaşamın inişli çıkışlı basamakları gibidir (Görsel 21). 
Hayat, zaman ve yaşamda miktarları değişen olayları anlatan 19. Yüzyıl Kars halısı örneğinde; kırmızı orta zeminin dört köşesindeki siyah üçgenlerde yıldız motifi bulunmaktadır. Siyah üçgenlerden kalan kırmızı zeminli alanda üç sekizgen desen; gece karanlığında parlayan yıldızlardan güneşin karanlıktan yükselişi, ortada parlak durumu ve batışında değişen ışık etkisi gibidir. Güneşin doğuşundan batışına geçen zaman ve ışık etkisi, kırmızı zeminde üçgen dizilimlerin oluşturduğu sekizgen güneş deseninde anlam kazanmıştır. Bitkisel desenli üç bordür, orta zeminde güneşin gün içindeki serüveni gibi oldukça başarılı bir anlatımdır. Ortada bulunan sekizgen desen ve beyaz zeminli bordür güneşin en parlak olduğu zamanla aynı durumu anlatmaktadır. Sarı zeminli iç bordür güneşin doğuşu, koyu zeminli dış bordür ise batışı gibidir. Diğer açıdan bakıldığında; hayat sarı 1şıkla başlar. İlkbaharda yapraklar sarı - yeşil tonlardadır. Doğada genel bir sarılık hakimdir. Yaz mevsiminde; orta sekizgende ve orta bordür zemin rengindeki gibi en parlak döneme ulaşılır. Sonbaharda ise; diş bordür zemin rengi gibi kahverengi tonlara döner. Hayatın başlangıcından bitişine yaşam evreleri, bitkisel desenlerden oluşan bu üç bordürle desenlenmiştir (Görsel 22).

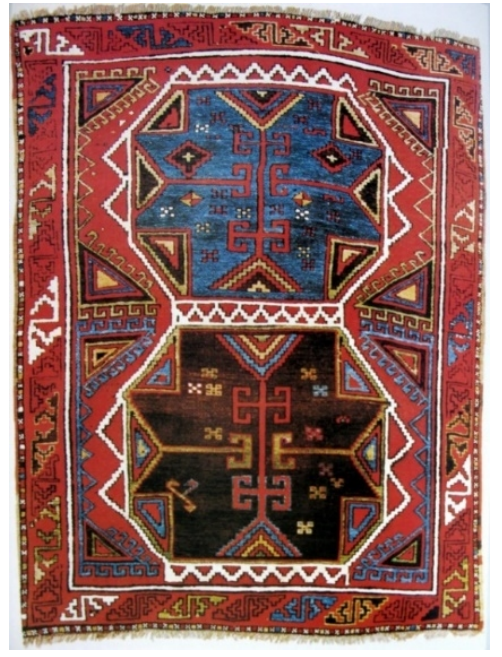

Görsel 21. Konya, Karapınar, 18. yüzyıl. 142x183 cm. Özel koleksiyon

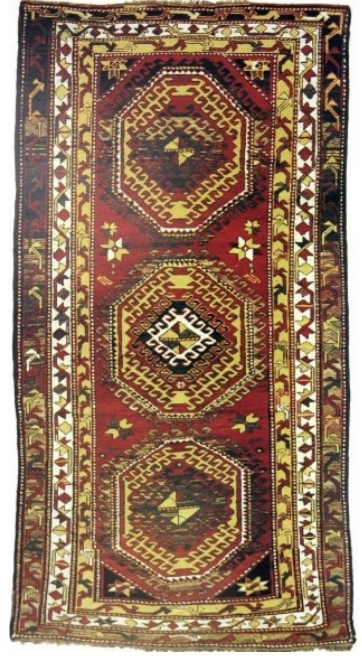

Görsel 22. Kars, 19. yüzy1l. 113 x 227 cm. Özel koleksiyon

Hayat ve zaman farkındalığı, gökyüzüne ve sonsuzluğa duyulan özlem duygusunun farklı kompozisyonlarından biri, 18. Yüzyıl Çanakkale halısıdır. Ortada bulunan büyük desen; gelişim, hareket, aktiflik ve enerjisiyle, zamanda kararlı bir yapıyı anlatır. Büyük desenin dikdörtgen içindeki yıldızlı sekizgen desenini, yaşamda gelişim sürecini temsil eden mavi üçgen dizilimler çevrelemektedir. Sekizgeni çevreleyen dikdörtgen ise, hayat ve zamanın kararlı yapısını temsil etmektedir. Deseni tamamlayan dikdörtgenin dışındaki bölümler ve orta zeminin köşelerinde yer alan üçgen desenler, yine zaman ve yaşamda değişen olayların süreçleriyle ilgilidir. Halının orta zemin kompozisyonunu bitkisel motiflerin bulunduğu sarı, yaşam rengindeki geniş bordür çevreler. Bordürde motiflerin ters ve düz sıralanışı, yine yaşamdaki aktif olayları temsil etmektedir. Tüm kompozisyonu çevreleyen bitkisel motiflerin dizildiği, kırmızı zeminli ince bordür güneşin batımı gibidir. Genel olarak; orta zeminde güneşin doğuşu ve batışındaki kararlılık, kenar desenler; zaman sürecinde değişen miktarlar, beyaz çizgili iç ince bordür; gündoğumuyla yaşamda başlayan hareketlilik ve enerji, sarı zeminli çizgi yaşamı, kırmızı zeminli bordür ise günbatımı gibi düşünülebilir (Görsel 23).

Yine; 18. Yüzyıl Konya halısı hayat, zaman kavramları ve sonsuzluk duygusunu temsil eden güzel bir örnektir. Orta zemin kompozisyonunun merkezinde bulunan yıldız ve dönen küçük üçgenlerin bulunduğu sekizgen motif doğum, hayatın başlangıcı ve dışa doğru giderek büyüyen hareketli bir yapı gibi düşünülebilir, ya da diğer açıdan güneş, dünya ya da parlayan büyük bir yıldız gibi de görülebilir. Köşeklerde yer alan üçgen desenler ve bu üçgenlerin etrafını saran küçük noktalar; gökyüzünün pırıltıları, mutluluk, enerji, ya da zaman ve yaşam sürecinde değişen miktarlarla ilgili kavramları temsil etmektedir. Orta zeminde yer alan yıldız motifleri ise, yine gökyüzü ve sonsuzlukla ilgili kavramlardır. Halının geniş bordür motifleri (Görsel 21) halı örneğindeki gibi yaşamın inişli çıkışlı basamaklarını temsil etmektedir (Görsel 24). 


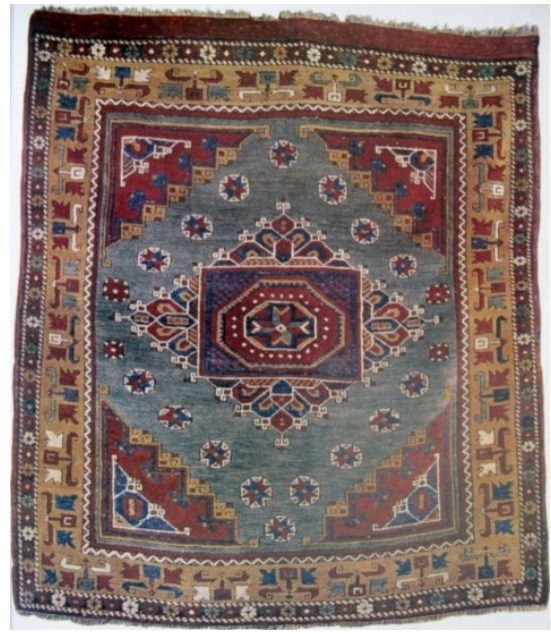

Görsel 23. Çanakkale, 18.yüzyıl.

New York, The Metropolitan Museum of Art

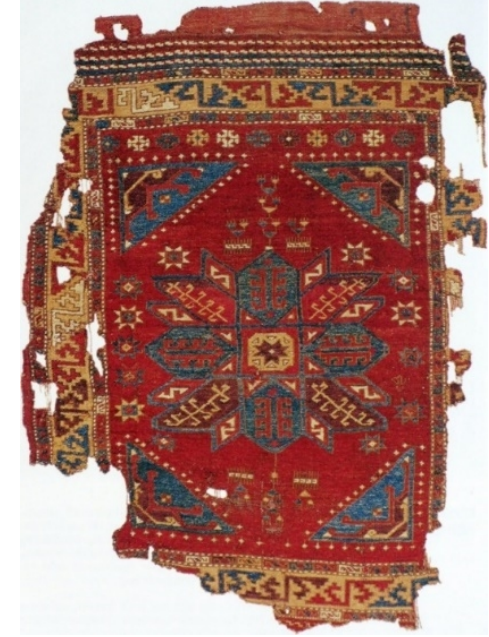

Görsel 24. Konya, 18. yüzy1l. 110x147 cm. Türk ve İslam Eserleri Müzesi

18. Yüzyıl Kütahya halısının orta deseninde doğum ya da hayatın başlangıcının dışa doğru gelişen aktif desen sıralaması, tıpkı güneşin doğuşu ve batışındaki eğri gibi, yaşamın değişen evrelerine benzer. Orta zeminin dört köşesindeki motifler hayatın kararlılığını, aralarda yer alan çizgisel yıldız motifleri ve küçük motifler gökyüzünün sonsuzluk duygusunu temsil etmektedir. Orta zeminin hayatta yükselen ve inen desen yapısını; hayatın bölümlerini anlatan sekizgen desenlerin sıralandığı geniş bordür çevreler. Bordürün sekizgen desenleri arasında zaman kavramı ve yaşam sürecinde değişen aktiflik ve miktar kavramlarını anlatan üçgen desenler yer almaktadır (Görsel 25).

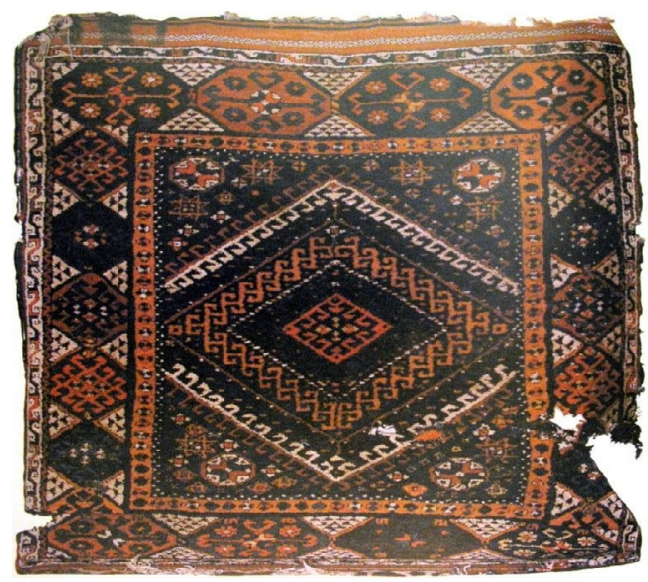

Görsel 25. Kütahya, 18. yüzyı1. 80x115 cm. Kütahya Ulu Cami

Hayat ve zaman kavramlarının görüldüğü farklı bir kompozisyon, 18. Yüzyıl Bergama halısıdır. Doğanın rengi, yeşil orta zeminde yer alan büyük kare desenin içinde, merkezde ve etrafında dönen yıldızlar; gökyüzü hareketlerini, köşelerdeki üçgen desenler; zaman sürecinde yaşamda başlayan ve biten aktiflik, hareket ve diğer kavramların kare içinde kararlı yapısını temsil etmektedir. Orta zeminin köşelerindeki dikdörtgen desenler aynı düşüncenin farklı söylemi gibidir. Ayrıca; hayat ve zamanın dışına çıkılamayan bilinen, belirli anlatımını güçlendirmektedir. Aralarda süreklilikle dizilen motiflerde hayatın canlılığı görülür. Orta zemini çevreleyen farklı bordürler doğadaki farklı yaşamları anlatır niteliktedir (Görsel 26). 


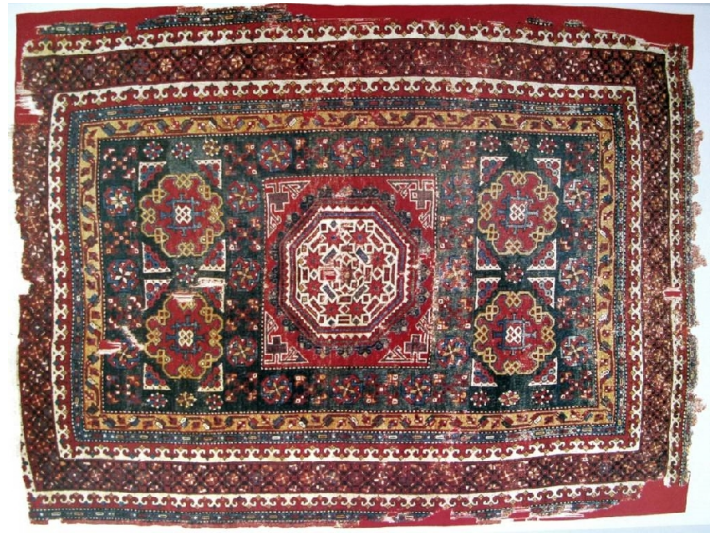

Görsel 26. Bergama,18. yüzyıl. $152 \times 210$ cm. Türk ve İslam Eserleri Müzesi, Env. No: 694

Başka bir kompozisyon şekli, mihrap desenli 18. Yüzyıl Çanakkale halısında hayat; zaman sınırları içinde giriş, gelişme sonuç bölümlerini anlatan kompozisyon şeklindedir. Alt ve üst bölümlerde yine yaşamdaki olayların çıkışlı, inişli miktarlarını temsil eden desenler görülmektedir (Görsel 27).

19. Yüzyıl Malatya halısında da yine yaşamda miktarları değişen olayların yükselen ve inen çizgisi; tekrar eden üç ayrı alan içinde, hayat ağacı desenlerinin bulunduğu giriş, gelişme ve sonuç bölümlerini temsil eden desenlerle görülmektedir (Sözen ve Tanyeli, 1986, 102). Orta zemini; dört birimden oluşan, kararlılığı temsil eden motiflerin dizildiği geniş bordür çevrelemektedir (Görsel 28).

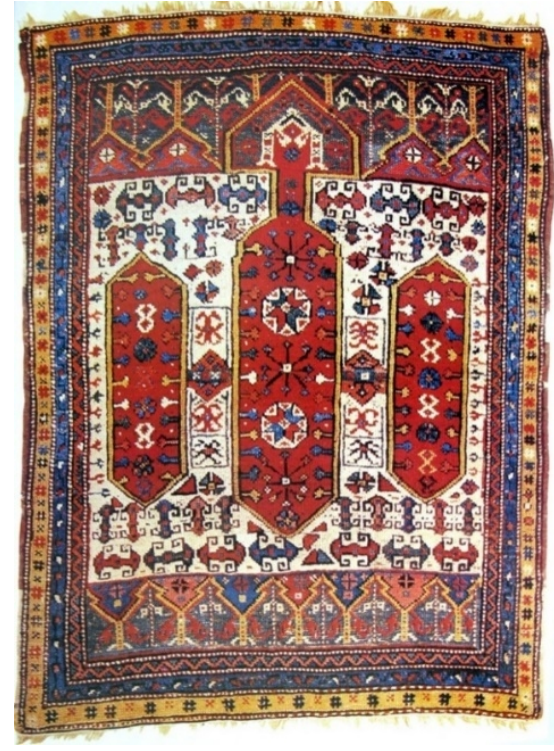

Görsel 27. Çanakkale, 18. yüzy1l. $91 \times 122 \mathrm{~cm}$. Özel koleksiyon

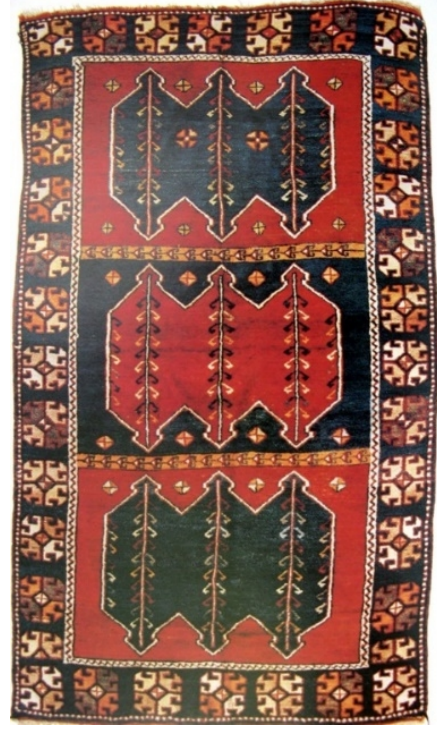

Görsel 28. Malatya, 19. yüzy1l. 100x200 cm. Özel koleksiyon

18. Yüzyıl Konya mihrap desenli halının orta zemininde; sonsuzluk düşüncesiyle tekrar eden her bir bölümünde güneşin doğuşundan batışına yükselen ve inen çizgisi gibi, hayatın içinde yükselen ve inen basamaklarında geçen zaman, yıllar, dünyanın dönüşü ve hayatı görmek mümkündür. Yıldızların bulunduğu siyah zeminli bölüm; gökyüzü ve geceyi, diğer bölümler; geçen zamanda değişen anları, her iki tarafta yükselen ve inen kare alanlarda bulunan yıldızlar; hayatlar geçse bile yıldızların sonsuzluğunu, gökyüzünün hissettirdiği duyguyu, sonsuzluk hayalini ve hayatın ötesindeki bilinmezliği temsil etmektedir. Orta zemini çevreleyen geniş bordürde yıldızların arasında küçük karelerden oluşan motifler, yaşamda değişen olaylarla geçen kararlı zaman sürecinde yıldızların sonsuzluk duygularını hissettirmektedir (Görsel 29).

19. Yüzyıl Antalya, Döşemealtı halısının orta zemininde yaşamın yükselen ve zirveden inen, içlerinde sekizgen motifler bulunan desen yapısı yine sonsuzluk duygusuyla hayatın kompozisyonudur. Gökyüzüne yükselme, hayat sonrasındaki açılan kapının ardındaki sonsuz bilinmezlik gibi duyguları temsil etmektedir. Orta zemini aynı duygularla desenlenen bordürler çevrelemektedir (Görsel 30). 


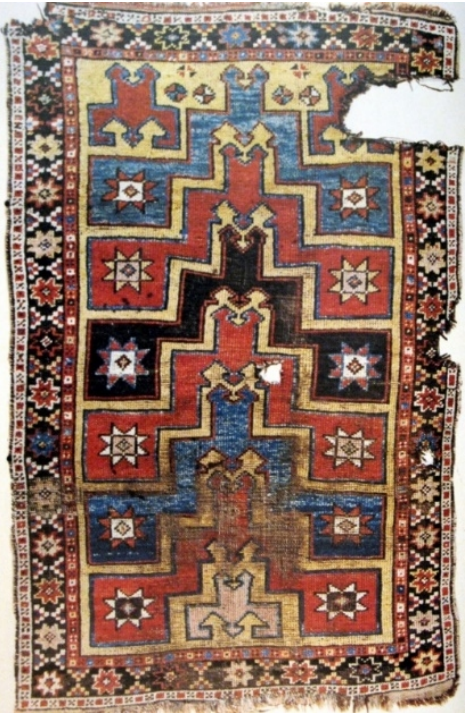

Görsel 29. Konya, 18. yüzy1l. 103x163 cm Özel koleksiyon

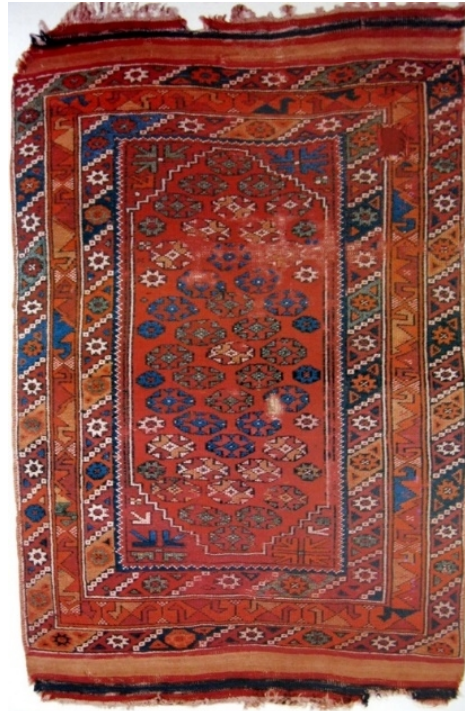

Görsel 30. Antalya, Döşemealtı, 18. yüzyıl 100x108 cm. Antalya Müzesi, Env. No: 8.28.73

\section{Sonuc}

Geçmişten günümüze Türk halılarının kompozisyonları düşünüldüğünde görülebilen, doğadaki pek çok olayın sessizliği gibidir. Pırıltılarla hızla büyüyen bir yaprağın esen rüzgârlarla sonbaharda düşmesi, güneşin hızla yükselen sarı 1şığından kırmızıya dönen günbatımına karşılık, gökyüzünün derin karanlığında parlayan yıldızların iç dünyada biçimlendirdiği hayat ve zaman duygusu halıların desen ve motiflerinde gizlidir. $\mathrm{Bu}$ nedenle Türk kültürünün estetik yorumlama gücüyle günümüze gelen birer öğreti belgeleridir.

Halı; kullanılıp, kolay vazgeçilen bir eşya sınıfında hiçbir zaman yer almamıştır. Dokuyan kişiyi temsil ettiği için özenle saklanmış ve gelecek nesillere hatıra olarak bırakılmıştır. Günümüze kalanlar bu değerle korunarak gelmişlerdir ve bu özelliğiyle de halılar geçen hayat ve zamanın temsilcileridir.

İnsanın en önemli farkındalığı olan hayat ve zaman kavramları, halıların yüzeyinde sonsuzluk ve gökyüzü kompozisyonlarıyla görülmektedir. Çünkü insanın ilk öğrendiği; hayat ve zaman gerçeğidir ve bilinçlenme süreciyle birlikte, hayat ve zamana karşı içinde gizli bir sitem saklar. Halılarda sonsuzluk özlemlerini dokuyanlar isimsiz sanatçılar olarak geleceğe kendilerinden iz bırakmışlardır.

Günümüz el halısı üretimlerinde en önemli sorun; neden ve nasıl olması gerektiği yeterince ve doğru araştırılıp, uygulanmayan kimlik sorunudur. Azalan üretimler pek çok düşüncede dönemini tamamlamış ve modasi geçmiş görülmekle birlikte, yenileri genelde turistik hatıra için yapılmaktadır. Bu durum köklü kültürümüzü yanlış temsil etmektedir. Çünkü turistik üretimler de geleceğe uzun yıllar kalacaktır. Diğer modern tasarım üretimleri düşünce zenginliği adına tabii ki yapılmalıdır ve ülkemizin halı üretim ve gelir potansiyeli için desteklenmelidir. Fakat kültürümüz ve bir bölgeden çıkışlı kompozisyonlar ve üretim kalitesiyle üretilen yeni halılar, kültürümüzün köklü geçmişini zedelememelidir. Ülkemizde nedenleri bilinerek anlatılan, doğru uygulanacak projelerle farkındalığa dayalı kompozisyonlar yapılabilir ve dokuyucunun duygu ve düşüncelerini temsil eden halılarla kültürümüzün sanat değeri, geleceğe düşünce zenginliği ve gelişerek aktarılabilir.

\section{Kaynakça}

Ana Britannica (C. 22). (1990). İstanbul: Ana Yayıncılık.

Hançerlioğlu, O. (1989). Felsefe sözlüğ̈̈ (7. Basım). İstanbul: Remzi Kitabevi.

Hançerlioğlu, O. (1993). Felsefe ansiklopedisi (2. Basım). C. 7. İstanbul: Remzi Kitabevi.

Hançerlioğlu, O. (1995). Düşünce tarihi (6. Basım). İstanbul: Remzi Kitabevi.

Sözen, M., \& Tanyeli, U. (1986). Sanat kavram ve terimleri sözlüğü. İstanbul: Remzi Kitabevi.

Thomson, G. (1976). İnsanın özü. (C. Üster, Çev.). İstanbul: Payel Yayınları. (Orijinal yayın tarihi, 1974). 
TDK. (1988). Türkçe Sözlük (C. 1 - 2). Ankara: Türk Dil Kurumu Yayınları.

Yetkin, Ş. (1991). Türk halı sanatı. Ankara: Türkiye İş Bankası Kültür Yayınları.

\section{Görsel Kaynakçası}

Görsel 1. Yeni Şafak. (2013). İstanbu'da başkadır güvercin hikayeleri [Fotoğraf]. Erişim adresi: https:/www.yenisafak.com/kultur-sanat/istanbulda-baskadir-guvercin-hikayeleri-508049

Görsel 2. Zamanda hayatın yaşam evreleri [Çizim].

Görsel 3. Ayın evreleri [Fotoğraf]. Erişim adresi: https://www.tapeciarnia.pl/edycja,224223

Görsel 3. NASA. (2019). Ayın hilal görünümü [Fotoğraf]. Saturday, August 03, 2019, 20:00 UT. Erişim adresi: https://svs.gsfc.nasa.gov/4442

Görsel 4. Ayın evreleri ve hayatın kararlı yapısının kare ile miktar çizimi [Çizim].

Görsel 5. Coşkun, G. (2017). Çınar yaprağı [Fotoğraf]. İletişim: galinagulsen@gmail.com

Görsel 6.Çiloğlu, G. (2019). Elin yapısı [Fotoğraf].

Görsel 7. Çiloğlu, H. (2018). Güneşin doğuşu [Fotoğraf].

Görsel 8. Çiloğlu, H. (2018). Güneşin batışı [Fotoğraf].

Görsel 9. Çiloğlu, H. (2012). Sonbaharda düşen yapraklar [Fotoğraf].

Görsel 10. Çiloğlu, H. (2014). Palmiye gövdesinde hayat bulan bitki [Fotoğraf].

Görsel 11. Çiloğlu, H. (2014). Palmiye gövdesinde hayatı sonlanan bitki [Fotoğraf].

Görsel 12. Çiloğlu, H. (2014). Palmiye ağacı tohumları [Fotoğraf].

Görsel 13. Çiloğlu, H. (2019). Topraktan yeni çıkan ve büyüyen bitkiler [Fotoğraf].

Görsel 14. Çiloğlu, H. (2019). Yapraklar [Fotoğraf].

Görsel 15. Anonim. (1992). Turkish Handwoven Carpets (2. Basım). Ankara: T. C. Kültür Bakanlı̆ğ Yayınları, C. 1, Code 0099

Görsel 16. Anonim. (1988). Turkish Handwoven Carpets (2. Basım). Ankara: T. C. Kültür Bakanlığı Yayınları, C. 2 , Code 0156

Görsel 17. Anonim. (1992). Turkish Handwoven Carpets (2. Basım). Ankara: T. C. Kültür Bakanlığı Yayınları, C. 1 , Code 0079

Görsel 18. Anonim. (1992). Turkish Handwoven Carpets (2. Basım). Ankara: T. C. Kültür Bakanlığı Yayınları, C. 1 , Code 0011

Görsel 19. Anonim. (1988). Turkish Handwoven Carpets (2. Basım). Ankara: T. C. Kültür Bakanlığı Yayınları, C. 2, Code 0140

Görsel 20. Anonim. (1988). Turkish Handwoven Carpets (2. Basım). Ankara: T. C. Kültür Bakanlığı Yayınları, C. 2, Code 0155

Görsel 21. Anonim. (1988). Turkish Handwoven Carpets (2. Basım). Ankara: T. C. Kültür Bakanlığı Yayınları, C. 2 , Code 0145

Görsel 22. Anonim. (1995). Turkish Handwoven Carpets (2. Basım). Ankara: T. C. Kültür Bakanlığı Yayınları, C. 5 , Code 0579

Görsel 23. Anonim. (1992). Turkish Handwoven Carpets (2. Basım). Ankara: T. C. Kültür Bakanlığı Yayınları, C. 1 , Code 0024

Görsel 24. Anonim. (1990). Turkish Handwoven Carpets (2. Basım). Ankara: T. C. Kültür Bakanlığı Yayınları, C. 4 , Code 0424 
Görsel 25. Anonim. (1992). Turkish Handwoven Carpets (2. Basım). Ankara: T. C. Kültür Bakanlığı Yayınları, C. 1 , Code 0016

Görsel 26. Anonim. (1988). Turkish Handwoven Carpets (2. Basım). Ankara: T. C. Kültür Bakanlığı Yayınları, C. 2 , Code 0118

Görsel 27. Anonim. (1992). Turkish Handwoven Carpets (2. Basım). Ankara: T. C. Kültür Bakanlığı Yayınları, C. 1 , Code 0014

Görsel 28. Anonim. (1995). Turkish Handwoven Carpets (2. Basım). Ankara: T. C. Kültür Bakanlığı Yayınları, C. 5, Code 0526

Görsel 29. Anonim. (1988). Turkish Handwoven Carpets (2. Basım). Ankara: T. C. Kültür Bakanlığ Yayınları, C. 2 , Code 0148

Görsel 30. Anonim. (1992). Turkish Handwoven Carpets (2. Basım). Ankara: T. C. Kültür Bakanlığı Yayınları, C. 1 , Code 0020 